\title{
Regulation of human breast epithelial stem cells
}

\author{
Robert B. Clarke*, Elizabeth Anderson†, Anthony Howell† \\ and Christopher S. Potten $\S$ \\ * Breast Biology Group and $\dagger$ Clinical Research Department, Paterson Institute for Cancer Research and $\ddagger C R-U K$ \\ Department of Medical Oncology, Christie Hospital NHS Trust, Wilmslow Road, Withington, Manchester, UK, and \\ $\S$ Epistem Ltd, Incubator Building, Grafton Street, Manchester, UK
}

Received 1 January 2003; revision accepted 22 May 2003

\begin{abstract}
Breast epithelial stem cells are thought to be the primary targets in the aetiology of breast cancer. As breast cancers are predominantly oestrogen and progesterone receptorpositive $\left(\mathrm{ER} \alpha / \mathrm{PR}^{+}\right)$, we investigated the biology of $\mathrm{ER} \alpha / \mathrm{PR}^{+}$cells and their relationship to stem cells in normal human breast epithelium. Several complementary approaches were used to characterize the stem-cell population and relate it to $\mathrm{ER} \alpha / \mathrm{PR}^{+}$cells, including dual label colocalization on tissue sections, isolation of a Hoechst dye-effluxing 'side population' using flow cytometry, and examination of DNA label retention. The intermediate or suprabasal population suggested by others to be breast stem cells comprises ER $\alpha /$ $\mathrm{PR}^{+}$cells that coexpress the putative stem-cell markers including cytokeratin 19. Human breast epithelial cells with Hoechst dye-effluxing 'side population' properties characteristic of mammary stem cells in mice were demonstrated by lack of expression of myoepithelial and luminal cell-specific antigens such as CALLA and MUC1 to be undifferentiated cells. Using DNA radiolabelling of human tissue implanted into athymic nude mice, a population of label-retaining putative stem cells (LRC) were shown to be enriched for cells expressing the putative stem-cell markers $\mathrm{p} 21^{\mathrm{CIP} 1 / \mathrm{WAF} 1}$ and Musashi-1, which, interestingly, were expressed in separate subpopulations of ER $\alpha / \mathrm{PR}^{+}$cells. Finally, expression patterns of Musashi-1 and Notch-1 in relation to ER $\alpha / \mathrm{PR}^{+}$and adjacent proliferating cells suggest that the evolutionarily conserved Delta/Notch signalling pathway regulates asymmetric division of the putative stem-cell population. The data suggest a model in which ER $\alpha / \mathrm{PR}^{+}$cells scattered through the epithelium are stem cells that self-renew through asymmetric cell division and generate patches of transit amplifying and differentiated cells. ER $\alpha / \mathrm{PR}^{+}$ breast cancers exhibit loss of the two key regulators of asymmetric cell division, Musashi1 and Notch-1 and thus may arise from symmetric division of the ER $\alpha / \mathrm{PR}^{+}$stem cell.
\end{abstract}

\section{INTRODUCTION}

Tissue-specific stem cells are defined by their ability to self-renew and to produce differentiated and functional cells. While differentiated cells tend to be short-lived, stem cells persist throughout the lifetime of an organism. For example, the short-lived, differentiated cells of skin and blood 
are produced from a small pool of long-lived stem cells (Dexter \& Spooncer 1987; Jones 1997; Watt 1998; Orkin 2000). Thus, the stem-cell type has been described as 'nature's gift to multicellular organisms' as they allow tissue development, replacement and repair (Fuchs \& Segre 2000). However, their longevity makes stem cells susceptible to accumulating genetic damage during self-renewal, and they must be regarded as targets for carcinogenic transformation. The development, differentiation and function of the mammary gland would not be possible without tissue-specific stem cells. Full development of mammary epithelium occurs only during pregnancy and lactation, to be followed at weaning by involution. The cycle of pregnancy-associated proliferation, differentiation, apoptosis and remodelling can occur many times during the reproductive lifespan of mammals, and may be explained by the presence of a long-lived population of stem cells that have a near-infinite propensity to produce functional cells. One implication of the 'multihit theory' of carcinogenesis is that cancer is a stem-cell disease. If this is the case, then breast-cancer prevention strategies must be targeted to mammary epithelial stem cells.

The resting human mammary gland consists of a branching ductal system and terminal ductal lobulo-alveolar units (TDLUs) or lobules, which are the functional domain of the premenopausal breast. Each lobule is lined by a layer of luminal epithelial cells surrounded by a basal layer of myoepithelial cells. TDLUs have been reported to be the site from which most breast tumours originate (Wellings et al. 1975). Furthermore, most breast tumours have the phenotype of luminal epithelial cells (Taylor-Papadimitriou et al. 1989). The presence of stem cells in the mammary gland and susceptibility to carcinogens appear to be related. The greatest concentration of stem cells is in terminal end bud and alveolar bud structures during pubertal development in rodents, and it is during this period that the gland is most sensitive to carcinogens (Russo \& Russo 1978a; Russo \& Russo 1978b). Similar structures exist in the breasts of prepubertal and adolescent women, and it is this age group that suffered the highest rates of breast cancer after irradiation due to the atomic detonations in Japan in 1945 (Dawson 1934; McGregor et al. 1977).

Although breast cancer might be considered a stem-cell disease, it is not clear whether the tumours seen clinically retain the characteristics of stem cells. Certainly, like putative stem cells, tumours express mainly markers of luminal cells, not myoepithelial cells (Taylor-Papadimitriou et al. 1989; Li et al. 1998; Perou et al. 1999; Perou et al. 2000; Sorlie et al. 2001; Korsching et al. 2002). On the other hand, it is feasible that the immortalizing or transforming step may occur during transit amplification or differentiation of stem-cell progeny, which may explain why many breast tumours acquire features of differentiation.

In addition, little is known about whether tumours contain stem cells equivalent to normal tissues. If this is the case, then therapies aimed at killing proliferating cells may have little impact on a small number of tumour stem cells that remain quiescent, but which may cause tumour repopulation following treatment. Stem cells may also be responsible for local or distant recurrence that may occur several years after initial treatment of the primary tumour. Tumour stem cells remain an area for speculation but results from one of the first studies to address this question are very exciting and merit further research (Dontu et al. 2003). It is therefore imperative that we identify tissue-specific stem cells and study their regulation in order to generate new targets for therapy that can prevent tumour stem cells from seeding tumour regrowth.

\section{EVIDENCE FOR A BREAST EPITHELIAL STEM CELL}

There is good evidence to suggest that the luminal and myoepithelial cell types of the normal breast arise from a shared, pluripotent stem cell. Many years ago, it was demonstrated that small 
fragments of the rodent duct or TEBs transplanted in cleared mammary fat pads of syngeneic hosts could develop an entire and functional mammary tree (DeOme et al. 1959; Hoshino \& Gardner 1967; Daniel et al. 1968; Ormerod \& Rudland 1986). Serial transplantation, allowing full differentiation each time, revealed that the capacity for regeneration was not infinite, being lost by the seventh transplant generation (Daniel \& Young 1971; Young et al. 1971). Surprisingly, the results indicated that the regenerative ability of mammary tissue from old mice was similar to that taken from young mice, and neither reproductive history nor reproductive state affected regenerative capacity. The authors concluded from their experiments that the eventual growth senescence of serially transplanted mammary epithelium was essentially a function of the number of stem-cell divisions that had taken place (Daniel \& Young 1971). More recently, using viral integration to mark and follow individual clones, it has been reported that a fully differentiated mammary gland can be derived from a single cell clone (Kordon \& Smith 1998). This study also estimated that the number of self-renewing stem-cell divisions that occur before senescence of the mammary transplants is 40-50. This is remarkably close to the number of doublings calculated for mortal eukaryotic cells before the onset of senescence in culture (Smith \& Chepko 2001).

Data demonstrating that the human breast is generated from stem cells have been provided by studies of the pattern of X-chromosome inactivation throughout the ductal and lobular epithelium. These showed that contiguous patches of epithelium with inactivation of the same X-chromosome were present, suggesting that the cells within the patch had been derived from the same stem cell (Tsai et al. 1996; Diallo et al. 2001). Further evidence for the existence of human breast stem cells comes from studies showing that the same genetic lesion can be detected throughout an individual lobule or duct within histologically normal mammary epithelium (Deng et al. 1996; Lakhani et al. 1996). Secondly, separated myoepithelial and luminal cells from the same breast region have similar patterns of loss of heterozygosity, suggesting a common progenitor (Lakhani et al. 1999).

\section{STEROID RECEPTOR EXPRESSION PATTERNS}

Ovarian steroids play a critical role in mammary gland development and tumorigenesis, acting through specific nuclear receptors expressed in target cells. Cells containing receptors for oestrogen and progesterone (ER and PR, respectively) are located in the luminal epithelium of the ductal and lobular structures (Petersen et al. 1987), and it has been estimated that receptor-positive cells account for $10-20 \%$ of the epithelial cell population. ER $\alpha$ and PR are coexpressed in luminal epithelial cells, but dividing cells are steroid receptor-negative, although often adjacent to steroid receptor-positive cells (Clarke et al. 1997; Brisken et al. 1998; Zeps et al. 1998; Russo et al. 1999; Saji et al. 2000; Seagroves et al. 2000). This separation appears to be disrupted early in breast tumorigenesis because actively dividing steroid receptor-positive tumour cells can be found in premalignant lesions such as atypical ductal hyperplasia (Shoker et al. 1999). As breast cancers are predominantly steroid receptor-positive, the aim of our studies was to examine the biology of steroid receptor-positive cells and their relationship to stem cells in normal human breast epithelium.

\section{INTERMEDIATE HUMAN BREAST CELLS EXPRESS STEROID RECEPTORS}

There is evidence from both rodents and humans that a population of division-competent 

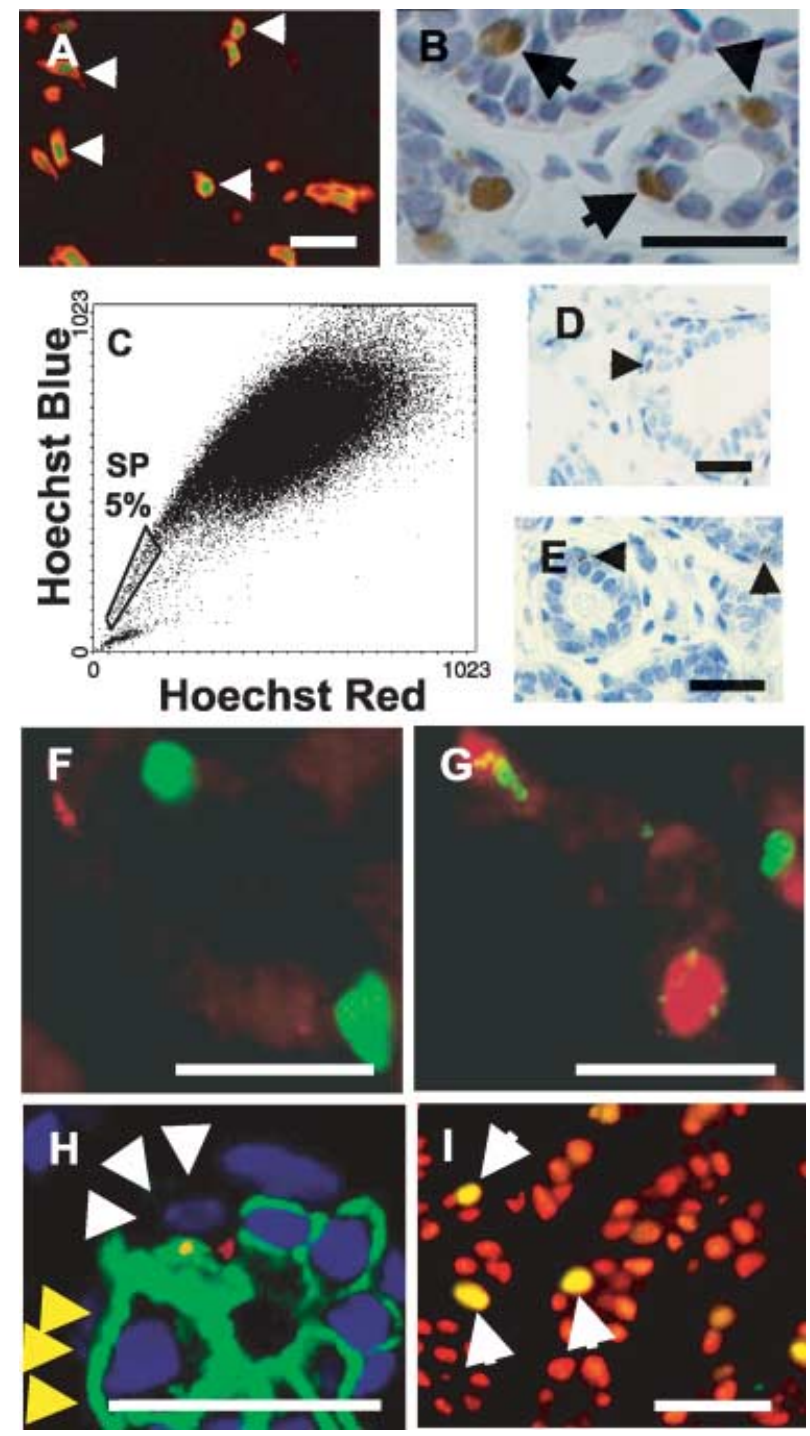

Figure 1. (A) Dual-label immunofluorescent localization of PR (FITC, green) and CK19 (Cy3, red) in breast epithelium, showing that all PR-positive cells express CK19 (arrows). (B) A representative image of ER $\alpha$ localization in lobular epithelium by immunohistochemistry, demonstrating that positive cells (brown) are often intermediate in position. (C) Gating of cells expressing BER-EP4 demonstrates that approximately $4.8 \pm 1.7 \%$ (mean \pm SEM; $n=21)$ of the epithelial population are SP cells (boxed region). Active Hoechst dye efflux was confirmed by demonstrating that $82 \pm 8 \%$ (mean \pm SEM) of cells in the boxed region were shifted to higher fluorescence levels after verapamil treatment to inhibit the activity of the ABCG2 transporter. (D) Photomicrographic image showing breast epithelial localization of the putative stem-cell marker $\mathrm{p} 21^{\mathrm{WAF} 1 / \mathrm{CIP} 1}$ by immunohistochemistry (arrow). (E) A representative photomicrograph of Msi-1 localization by immunohistochemistry in human breast epithelium demonstrating the perinuclear, punctate pattern of staining in infrequent cells (arrows). (F) Dual-label immunofluorescence for Ki67 (FITC, green) and Msi-1 $\left(\mathrm{Cy} 3\right.$, red) localization in breast epithelium. Proliferating cells do not express Msi-1, but are often adjacent to Msi ${ }^{+}$cells. (G) Dual-label PR (TRITC, red) and Msi-1 (FITC, green) immunofluorescent localization in breast epithelium showing that PR-positive cells express Msi-1. (H) A representative image of dual-label Notch-1 (FITC, green) and Msi-1 (Cy3, red) immunofluorescent localization in breast epithelium illustrating that Notch-1 is expressed on the membrane of 
mammary epithelial cells of a distinctive morphology can be found in a position intermediate between the basal and luminal cells (Smith et al. 1984; Ferguson 1985; Smith \& Medina 1988; Chepko \& Smith 1997). These intermediate cells are distinguished by their pale-staining cytoplasm under both light and electron microscopy (Chepko \& Smith 1997). They have few cellular organelles, pale nuclei and are found as a small light cells (SLC) and as an undifferentiated large light cells (ULLC). Their infrequent occurrence, alone or in pairs, and their undifferentiated character has made intermediate cells the focus of suggestions that they may be the mammary stem cell. There is some existing and some emerging evidence supporting this suggestion. Firstly, when mammary epithelial cells from nulliparous mice are placed in culture, it is the pale-staining cells that divide first, irrespective of whether or not hormones are present in the medium (Smith $\&$ Medina 1988). In the presence of the lactogenic hormones insulin, hydrocortisone and prolactin, groups of pale cells gradually disappear and darker cells producing milk proteins appear. In the absence of lactogenic hormones, pale cells remain and no milk proteins are produced (Smith \& Medina 1988; Chepko \& Smith 1997). More recently, it has been shown that pale-staining cells are depleted in growth-senescent serial mammary epithelial transplants and that their disappearance coincides with growth cessation (Smith et al. 2002). Thus, in rodents the results of in vitro and in vivo experiments suggest that the pale-staining or light cells situated between the luminal and the myo-epithelial cell layers are the most likely candidates for a stem-cell population.

These data seemingly contradict previous studies in both human and rodent studies, where a stem-cell type that is multipotent in culture was demonstrated to be part of the luminal cell population (Stingl et al. 1998; Pechoux et al. 1999; Smalley et al. 1999; Stingl et al. 2001). However, a recent study of human breast cells used these contradictory observations to predict that luminal cells that did not contact the lumen would not express the apical membrane-specific sialomucin MUC-1, but would express the luminal epithelial-specific antigen (ESA). Accordingly, an $\mathrm{ESA}^{+} / \mathrm{MUC}-1^{-}$population that can give rise to both luminal and myoepithelial cell types in culture has been isolated (Gudjonsson et al. 2002). These cells were also shown to express cytokeratin (CK)19 (Gudjonsson et al. 2002). Therefore, we analysed CK19 expression and its relationship to proliferating cells and those expressing steroid receptors. In many lobules, CK19 expression was homogeneous in that all luminal cells were stained; in others, CK19 expression was scattered throughout the lobule and labelled the cytoplasm of infrequent cells that rarely contained the proliferation-associated nuclear antigen Ki67. However, these scattered CK19-positive cells were frequently steroid receptor positive and 98.5 $\pm 0.6 \%$ (mean \pm SEM) steroid receptor-positive cells were CK-19 positive (Fig. 1A). Next, the position of ER $\alpha$ - and PR-positive cells in relation to the luminal and myo-epithelial cell layers was assessed in 10 samples of normal human breast tissue. In this particular group, $18.2 \pm 1.8 \%$ of cells were ER $\alpha$ positive and $18.4 \pm 3.5 \%$ were PR positive, and $72 \pm 2 \%$ and $73 \pm 3 \%$ of these ER $\alpha$ - and PRpositive cells, respectively, were in an intermediate position (Fig. 1B). We also observed that the nuclei of the $\mathrm{ER} \alpha^{+} / \mathrm{PR}^{+}$cells were larger than those of the myoepithelial and luminal cells (Fig. 1B). Both the intermediate location and the nuclear morphology of the steroid receptorpositive cells were similar to stem cells that have been described as ULLC in ultrastuctural studies (Smith \& Chepko 2001).

many luminal cells (yellow arrowheads) but is depleted from the membrane in Msi-1-positive cells (white arrowheads). (I) Dual-label Ki67 (FITC, green) and ER $\alpha(\mathrm{Cy} 3$, red) immunofluorescent localization in a human breast tumour illustrating that, in contrast to normal epithelium, the proliferating cells express ER $\alpha$ and appear yellow on the merged image (arrows). Bars $=50 \mu \mathrm{m}$. 


\section{SIDE POPULATION CELLS}

In order to characterize putative epithelial stem cells further, we employed a method successfully used for stem-cell isolation in other tissues. The technique consists of staining isolated cells with Hoechst 33342 followed by flow cytometric analysis to sort a 'side population' (SP) of cells that efflux the fluorescent dye (Goodell et al. 1997). Haematopoietic cells that efflux Hoechst 33342 in this way can reconstitute the bone marrow of lethally irradiated mice, suggesting that they are stem cells (Goodell et al. 1997; Jackson et al. 1999; McKinney-Freeman et al. 2002). The method has now been used to isolate an SP from mouse mammary glands. This shows that mouse mammary SP cells are enriched for expression of three putative stem-cell markers; Sca-1, $\alpha 6$-integrin and telomerase (Alvi et al. 2002; Welm et al. 2002). The percentage of mouse mammary SP cells was estimated to be $2-3 \%$ of all epithelial cells in one study (Welm et al. 2002) and $0.5 \%$ of total cells in the other (Alvi et al. 2002). Alvi et al. have further reported that nearly half of the SP cells were steroid receptor-positive and have produced preliminary data suggesting the presence of a similar SP population in human breast epithelium (Alvi et al. 2002).

In our studies, we have combined flow cytometric analysis of Hoechst dye efflux with use of fluorescence-conjugated epithelium-specific antibodies to define the human breast epithelial SP cells. The antibodies used were BER-EP4, which recognizes all epithelial cells; CALLA, which is specifically expressed on basal myoepithelial cells; and EMA, which recognizes MUC1 protein expressed only on the apical membrane of luminal cells. We found that $4.8 \pm 1.7 \%$ of breast epithelial cells defined by BER-EP4 were low in Hoechst fluorescence and that these constituted the SP cells (Fig. 1C). This proportion of SP cells is consistent with previous estimates of the percentage of stem cells in the rodent mammary gland (Smith \& Chepko 2001; Welm et al. 2002). Efflux of Hoechst dye by SP cells is thought to be via the ABCG2 membranetransporter protein and can be inhibited by the drug verapamil (Zhou et al. 2001). We were able to shift $82 \pm 8 \%$ of SP cells to higher fluorescence using verapamil. In 21 normal breast samples analysed, an average $29 \pm 3 \%$ of isolated cells expressed BOR-EP4, of which $46 \%$ expressed CALLA, 25\% expressed MUC1 and 29\% expressed neither. In contrast, $67 \%$ of the SP cells consisted of CALLA/MUC1-negative epithelial cells, suggesting that they are the intermediate, multipotent population described previously (Stingl et al. 2001).

\section{DNA LABEL-RETAINING CELLS EXPRESS P2 $1^{\text {WAF } 1 / C I P 1}$ AND MUSASHI-1}

Two studies of the mouse mammary gland have used DNA-label retention as a marker for the stem-cell population. The technique has been used previously to label putative skin and intestinal stem cells (Potten \& Morris 1988; Potten \& Loeffler 1990). It relies on the dilution of DNA label when a cell divides such that it is undetectable after a small number of divisions. As stem cells are thought to be quiescent compared with their progeny, which undergo transit amplification and form the majority of proliferating cells within a tissue, they would be expected to retain label over long periods. In addition, stem cells may retain label through the selective segregation of old and new DNA strands at division, as has been shown in the intestinal epithelium (Cairns 1975; Potten et al. 2002).

Two groups have reported attempts to define mammary gland stem cells in the mouse using injection of DNA label and a pulse-chase experiment to characterize label-retaining cells (LRC). 
The studies differed in the DNA label that was used, the developmental stage at which labelling was conducted and the length for which LRC were followed. Not surprisingly perhaps, the studies produced different results. In the first study, tritiated thymidine $\left({ }^{3} \mathrm{H}-\mathrm{dT}\right)$ label was injected into 10-12-week-old mice and the LRC were followed for up to 3 weeks (Zeps et al. 1996; Zeps et al. 1998). At 2 weeks, the number of LRC was small, comprising less than $0.1-1 \%$ of epithelial cells depending on the stage of oestrous at injection (Zeps et al. 1996). Interestingly, of the heavily labelled LRC, 95\% expressed ER $\alpha$, whereas the remaining 5\% of LRC were ER $\alpha$-negative basal cells (Zeps et al. 1998). In the second study, the DNA label was bromo-deoxyuridine (BrdU) given continuously over a 2-week period to mice between the ages of 3 and 5 weeks and the LRC followed until the mice were 13 weeks old (Welm et al. 2002). The period of labelling in this study covers the beginning of puberty in the mouse, and it seems probable that more stem-cell division might occur in early puberty than after puberty (Zeps et al. 1996; Zeps et al. 1998). Two weeks following the labelling period in the second study, less than $30 \%$ of LRC expressed progesterone receptor (PR), and at 9 weeks, less than 2\% of LRC were PR-positive (Welm et al. 2002). No relationship between the strength of DNA label in LRC and steroid receptor was reported. Some of the LRC at 9 weeks following labelling were shown to be undifferentiated in character, as they lacked cytokeratins 14 and 18, which are indicative of myoepithelial and luminal epithelial cells, respectively (Welm et al. 2002). The data from these two studies can be interpreted as indicating that there are at least two populations of stem cells: a long-lived, mainly quiescent, steroid receptor-negative stem cell that survives throughout the pubertal period, and a shorter lived, less quiescent, steroid receptor-positive stem cell that is more active during postpubertal oestrous cycles.

We have studied LRC in the human breast using an athymic nude mouse model in which the breast tissue is implanted subcutaneously. The fate of lobular epithelial cells dividing in response to oestrogen was tracked by administering the DNA label 1 week after the start of oestrogen treatment and observing the LRC for a period of 2 weeks in the continued presence of the hormone ( $2 \mathrm{mg}$ oestradiol pellet). The total level of epithelial cell proliferation remained constant throughout the 2-week period and averaged $5.9 \pm 1.1 \% \mathrm{Ki67}$-positive epithelial cells and $2.6 \pm 0.2 \%$ by BrdU incorporation. We assessed the frequency of staining of LRC with antibodies to two putative stem-cell markers, the CDKI p21 $1^{\text {WAF1/CIP1 }}$ (Topley et al. 1999; Cheng et al. 2000) and a novel stem-cell marker, the RNA-binding protein Musashi-1 (Msi-1) (Sakakibara et al. 1996).

The CDKI p2 ${ }^{\mathrm{CIP} 1}$ has been proposed to maintain skin and haemopoietic stem-cell quiescence, as its deletion in $\mathrm{p} 21^{\mathrm{CIP} 1}$-null mice leads to depletion of stem cells in these tissues (Topley et al. 1999; Cheng et al. 2000). Immunohistochemical detection of $\mathrm{p} 21^{\mathrm{WAF} 1 / \mathrm{CIP} 1}$-positive cells in normal breast lobules indicated that they were intermediate in location and that they possessed relatively small nuclei (Fig. 1D). This location and nuclear morphology is characteristic of the ultrastructurally defined small light cells (SLC) that have been described as undifferentiated mammary stem cells (Smith \& Chepko 2001). p2 $1^{\mathrm{WAF} 1 / \mathrm{CIP} 1}$ expression is infrequent in lobular epithelium, accounting for $0.7 \pm 0.4 \%$ of cells, but $8.6 \% \pm 1.9 \%$ of LRC are positive.

Msi-1 is the human homologue of Drosophila Musashi protein (Nakamura et al. 1994; Okabe et al. 2001). It is a 362-amino acid RNA-binding protein involved in the Delta/Notch signalling pathway that operates during asymmetric cell division (Imai et al. 2001; Okabe et al. 2001; Okano et al. 2002). Msi-1 is strongly expressed in murine neural and intestinal stem cells (Sakakibara et al. 1996; Potten et al. 2003). It is infrequently observed in lobular epithelium and has a distinctive pattern of staining that is punctate and perinuclear in appearance (Fig. 1E). Msi-1 staining is apparent in $0.6 \pm 0.1 \%$ of lobular cells, whereas $7.1 \pm 2.4 \%$ of LRC are Msi-1-positive. Msi-1 is expressed at a similar frequency to $\mathrm{p} 21^{\mathrm{WAF} 1 / \mathrm{CIP} 1}$ in lobular epithelial 
cells $(0.6 \%$ vs. $0.7 \%)$ and includes both intermediate and luminal cells. Both $\mathrm{p} 21^{\mathrm{CIP} 1}$ and Msi-1 staining suggest that a proportion of LRC are stem cells.

\section{RELATIONSHIP OF PUTATIVE STEM-CELL MARKERS TO STEROID RECEPTOR EXPRESSION}

The majority of steroid receptor-positive cells lie in an intermediate position in lobular epithelium, and the majority of epithelial SP cells are likely to be intermediate as they express neither the basal marker CALLA nor the apical membrane marker EMA. Steroid receptor-positive cells express CK19, a marker previously associated with a stem-cell population (Gudjonsson et al. 2002). Taken together, these data suggest that steroid receptor-positive cells may include a stem-cell population, and we examined the relationship of cells expressing steroid receptors to those expressing $\mathrm{p} 21^{\mathrm{WAF} 1 / \mathrm{CIP} 1}$ and Msi-1 that we have demonstrated to be enriched in human breast LRC. This showed that $\mathrm{p} 21^{\mathrm{WAF} 1 / \mathrm{CIP} 1}$ expression was closely associated with expression of steroid receptors in that $92 \pm 2.9 \%$ of $\mathrm{p} 21^{\mathrm{WAF} 1 / \mathrm{CIP} 1}$-positive breast epithelial cells expressed PR in immunofluorescent colocalization studies. Lobular epithelial cells expressing Msi-1 did not express the proliferation-associated nuclear antigen Ki67, but were often adjacent to them (Fig. 1F). When PR expression and Msi-1 were examined by dual-label immunofluorescence, $67 \pm 6 \%$ of Msi-1-positive cells expressed steroid receptors (Fig. 1G). Because Msi-1 has been shown to be a positive regulator of Notch signalling through its interaction with Numb mRNA and repression of translation, it has been proposed that Msi-1 regulates asymmetric cell division at the stem-cell/transit-cell boundary through Delta/Notch signalling (Imai et al. 2001). Delta/ Notch signalling is an evolutionarily conserved pathway that regulates the stem-cell/transit-cell boundary in both invertebrate and mammalian tissues (Lowell et al. 2000; Imai et al. 2001; Okabe et al. 2001; Kopan 2002). At this boundary, an asymmetric stem/progenitor cell division specifies one daughter cell to replace the stem/progenitor cell and the other to enter the transit amplifying population that multiplies to produce differentiated lineages. This suggests that in cells in which steroid receptors and Msi-1 are coexpressed, Numb would be down-regulated, leading to cleavage of the Notch cytoplasmic domain and its translocation to the nucleus where it is known to positively regulate CSL transcription factors (Kopan 2002). We therefore analysed the location of the Notch-1 cytoplasmic domain that has been reported to be associated with Msi-1 expression in neural stem cells (Kanemura et al. 2001).

We found that Notch-1 expression was confined mainly to the membrane of epithelial cells where it is inactive. However, in Msi-positive cells, membrane staining was absent, suggesting that Notch-1 had been cleaved from the membrane and translocated to the nucleus (Fig. 1H). This explanation is in agreement with studies on murine neural cells where Notch-1 translocates to the nucleus only in Msi-1-positive stem cells (Imai et al. 2001). These patterns of Msi-1 and Notch-1 expression suggest that when a breast stem cell divides, one daughter cell expresses Msi-1 and replaces the stem cell, while in the other Msi-1-negative daughter cell, Notch-1 remains inactive and the cell undergoes transit amplification before differentiating (Fig. 2A).

We reported previously that while steroid receptor expression and proliferation occur in separate cells in the normal breast, proliferating breast tumour cells in vivo often express ER $\alpha$ (Clarke et al. 1997). The ER $\alpha$-positive tumours selected for analysis contained an average of $78 \pm 3 \%(n=20)$ ER $\alpha$-positive cells whereas $6.8 \pm 1.2 \%$ of cells were proliferating, as indicated by Ki67 immunofluorescence. In direct contrast to the normal breast, $87 \pm 3 \%$ of the Ki67-positive cells expressed ER $\alpha$ (Fig. 1I). Furthermore, analysis of Msi-1 and Notch-1 expression in these tumours revealed 


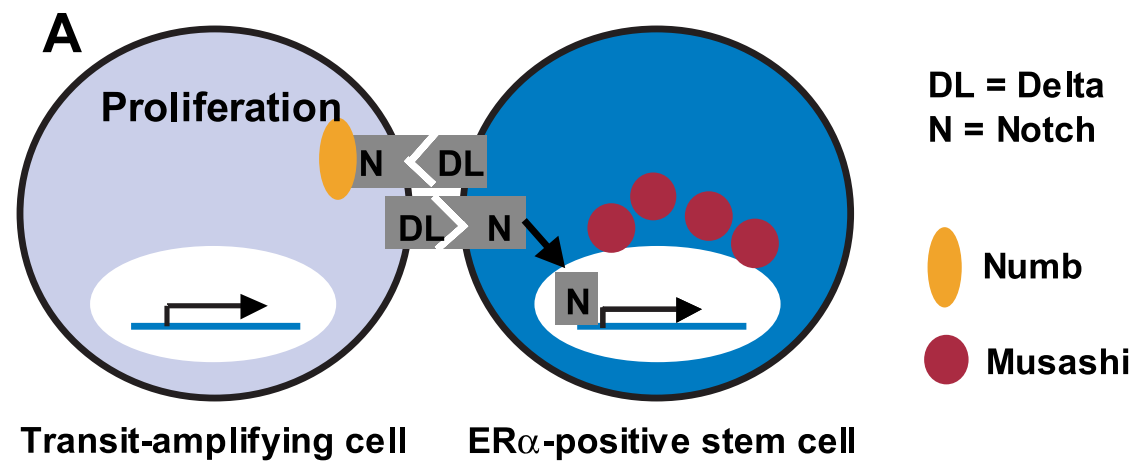

B

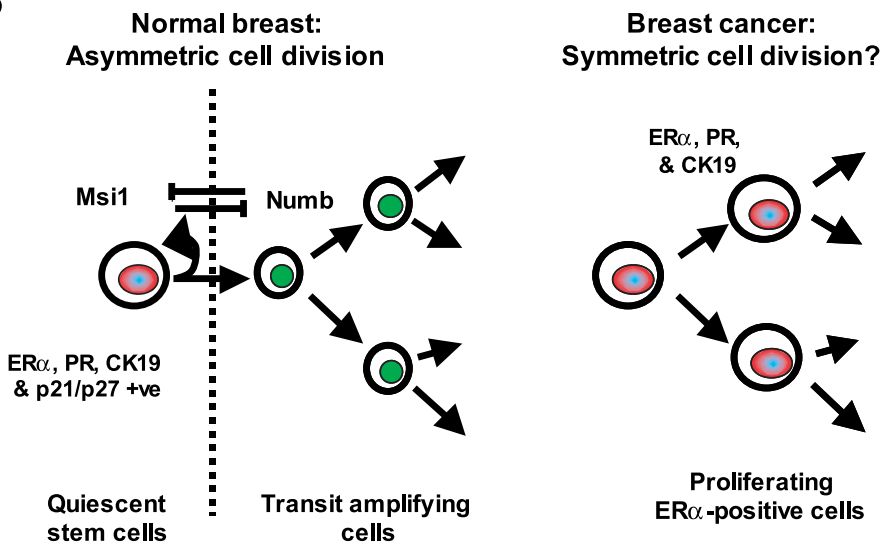

Figure 2. Models of the hierarchy between putative human breast epithelial stem cells and their progeny. (A) A schematic representation of a steroid receptor positive breast epithelial cell and an adjacent proliferating cell, demonstrating the localization of Msi-1 to the perinuclear region of the steroid receptor-positive cell. Msi-1 is proposed to target and degrade Numb mRNA, preventing its translation and allowing activation of Notch-1 signalling to the nucleus (Okano et al. 2002). In the adjacent transit amplifying daughter cell, which does not express Msi-1, Numb protein binds the Notch-1 cytoplasmic domain, preventing its activation. (B) Models of stem-cell division in the normal and neoplastic breast epithelium. Steroid receptor-positive cells occupy an intermediate location in the epithelium and express CK19, p2 $1^{\mathrm{WAF} 1 / \mathrm{CIP} 1}$ and Msi-1, markers of putative stem cells. Msi-1 and Delta/Notch signalling may regulate self-renewal of the stem cell and production of the transit amplifying population through the process of asymmetric cell division, as described above where Msi-1 and Numb act in opposing pathways to bestow different fates upon the two daughter cells following a stem-ell division (left). In steroid receptor-positive breast cancer, loss of both Msi-1 and Notch-1 may disrupt normal regulation of asymmetric stem-cell division, allowing symmetric division and resulting in the production of two identical daughter cells (right).

total loss of these proteins, suggesting that an alteration in signalling through Delta/Notch may lead to the symmetric rather than asymmetric division of ER $\alpha$-positive tumour cells (Fig. 2B).

\section{CONCLUSIONS}

We have employed several complementary approaches to investigate human breast epithelial stem cells and their relationship to both the proliferative population and steroid receptor-expressing 
cells. Our results are consistent with the hypothesis that normal lobular human breast epithelium is hierarchical in organization, with a small number of scattered quiescent stem cells (detected by $\mathrm{p} 21^{\mathrm{WAF} 1 / \mathrm{CIP} 1}$ and Msi-1 staining). These cells may overlap with the 'side population' of potential stem cells, which we found to be mainly 'intermediate' in character as they lack markers of either the basal myoepithelial cells (detected by CALLA staining) or the luminal cells that have an apical membrane (detected by EMA staining). ER $\alpha / \mathrm{PR}^{+}$cells are also intermediate in position, have enlarged nuclear morphology and express CK19 and, in some cases, Msi-1. These four characteristics have all been reported to be indicative of putative stem cells (Michel et al. 1996; Good et al. 1998; Kaneko et al. 2000; Smith \& Chepko 2001; Stingl et al. 2001; Gudjonsson et al. 2002). This suggests that the pool of potential stem cells includes some $\mathrm{ER} \alpha / \mathrm{PR}^{+}$cells. The majority of human breast tumours express both CK19 and ER $\alpha$ (TaylorPapadimitriou et al. 1989), suggesting that the intermediate cells of normal breast lobular epithelium are potential targets for neoplastic transformation. As stem cells have increased long-term replicative capacity, which is necessary for clonal expansion, they may accumulate and perpetuate the mutations that are required for tumorigenesis to occur (Smith 2002; Welm et al. 2002).

In the normal breast, the production of transit amplifying cells and differentiated cell lineages from stem cells is likely to occur through asymmetric cell division, where one daughter cell remains a stem cell and the other undergoes transit amplification before differentiating. In both invertebrate and mammalian tissues, asymmetric cell division is regulated by a conserved pathway involving Delta/Notch signalling between daughter cells at the stem-cell/transit-cell boundary (Lowell et al. 2000; Imai et al. 2001; Okabe et al. 2001; Kopan 2002). Our data indicate that Msi-1 is expressed in ER $\alpha / \mathrm{PR}$-positive cells and that Notch-1 is absent in their cell membrane. This suggests Delta/Notch communication between Msi-1/steroid receptor-positive cells and adjacent proliferating cells, perhaps following asymmetric division of a stem cell.

Labelling experiments suggest that the proliferative transit amplifying population of cells undergo a small number of divisions before exiting the cell cycle. The number of divisions is difficult to estimate as cells that divide a large number of times are likely to lose their DNA label through dilution. However, we believe that LRC exit from the cell cycle following 1-2 divisions over a 2-week period, suggesting that the differentiated cell lineages are continually replaced by production of new transit amplifying cells. Following the 2-week chase period, approximately $8 \%$ of LRC contained Msi- 1 and $\mathrm{p} 21^{\mathrm{WAF} 1 / \mathrm{CIP} 1}$. In similar labelling studies using mouse mammary gland epithelium (Welm et al. 2002), steroid receptors were expressed in many LRC in the short term, but over an extended chase period, steroid receptor-positive LRC decreased in number. This suggests that they divided more frequently than steroid receptor-negative stem cells that were enriched in the longer-term chase period. In addition, we have shown that LRC express the putative stem-cell markers Msi-1 and p21 $\mathrm{WAF1/CIP1}$, and that Msi-1 colocalizes with steroid receptors. Taken together, these data suggest a model where a hierarchy of stem cells produce and regulate the transit amplifying population that are destined to differentiate following a small number of cell divisions (Fig. 2B). Longer-term chase periods following DNA labelling will be required to ascertain the contribution of stem cells with different characteristics to this process, the relative frequency of cell division in these stem-cell compartments and the longevity of each of these stem-cell types. One model predicts that the more primitive stem cells are necessary for the clonal derivation of large areas of epithelium similar to the patches seen in X-chromosome inactivation studies (Tsai et al. 1996; Diallo et al. 2001). The scattered 'intermediate' CK19/

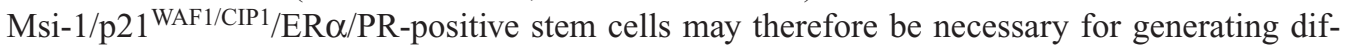
ferentiated cells within a smaller patch of lobular epithelium in response to the cyclical release of hormones during menstrual cycles. A model where there is a hierarchical organization of 
generally quiescent epithelial stem cells surrounded by proliferating cells and differentiated progeny arranged in patches is similar to that seen in the basal epidermis of the skin (Potten \& Morris 1988; MacKenzie 1997; Kolodka et al. 1998; Jensen et al. 1999). We speculate that the stem cells that persist in the breast epithelium during prolonged exposure to menstrual cycles uninterrupted by pregnancy would accumulate genetic changes leading to malignant transformation, and that this may explain the prevalence of CK19- and steroid receptor-positive breast tumours. Loss of Msi-1 and Notch-1 expression in ER $\alpha$-positive breast tumours may help to explain why proliferating tumour cells are mainly ER $\alpha$ positive (Clarke et al. 1997; Shoker et al. 1999). The data suggest that ER $\alpha$-positive breast tumour cells lack the ability to divide asymmetrically, instead undergoing symmetric divisions to produce two ER $\alpha$-positive daughter cells.

In summary, we have accumulated evidence to support a model in which some steroid receptor-positive cells act as a stem-cell type in the human mammary gland. Clonogenic assays and transplantation studies to confirm their function as long-lived stem cells remain more difficult than in the rodent. Such studies are in progress in our laboratory and those of others. Application of SP isolation in combination with the markers that we have highlighted should provide the tools for future study of the stem-cell type that resembles the phenotype of the majority of human breast tumours. Our observations suggest a testable model for the further understanding of human breast biology and breast cancer development.

\section{REFERENCES}

Alvi AJ, Clayton H, Joshi C, Enver T, Ashworth A, Vivanco MM, Dale TC, Smalley MJ (2002) Functional and molecular characterisation of mammary side population cells. Breast Cancer Res. 5, R1.

Brisken C, Park S, Vass T, Lydon JP, O’Malley BW, Weinberg RA (1998) A paracrine role for the epithelial progesterone receptor in mammary gland development. Proc. Natl Acad. Sci. USA 95, 5076.

CAIRNS J (1975) Mutation selection and the natural history of cancer. Nature 255, 197.

Cheng T, Rodrigues N, Shen H, Yang Y, Dombkowski D, Sykes M, Scadden DT (2000) Hematopoietic stem cell quiescence maintained by p21cip1/waf1. Science 287, 1804.

Chepкo G, Sмiтh GH (1997) Three division-competent, structurally-distinct cell populations contribute to murine mammary epithelial renewal. Tissue Cell 29, 239.

Clarke RB, Howell A, Potten CS, Anderson E (1997) Dissociation between steroid receptor expression and cell proliferation in the human breast. Cancer Res. 57, 4987.

Daniel CW, De Ome KB, Young JT, Blair PB, Faulkin LJ, JR (1968) The in vivo life span of normal and preneoplastic mouse mammary glands: a serial transplantation study. Proc. Natl Acad. Sci. USA 61, 53.

DANIEL CW, Young LJ (1971) Influence of cell division on an aging process. Life span of mouse mammary epithelium during serial propagation in vivo. Exp. Cell Res. 65, 27.

DAwson EK (1934) A histological study of the normal mamma in relation to tumour growth. Edinburgh Med. J. 41, 653.

Deng G, Lu Y, Zlotnikov G, Thor AD, Smith HS (1996) Loss of heterozygosity in normal tissue adjacent to breast carcinomas. Science 274, 2057.

DeOme KB, Faulkin LJ JR, Bern HA, Blair PB (1959) Development of mammary tumors from hyperplastic alveolar nodules transplanted into gland-free mammary fat pads of female $\mathrm{C} 3 \mathrm{H}$ mice. Cancer Res. 19, 515.

Dexter TM, Spooncer E (1987) Growth and differentiation in the hemopoietic system. Ann. Rev. Cell. Biol. 3 , 423.

Diallo R, Schaefer KL, Poremba C, Shivazi N, Willmann V, Buerger H, Dockhorn-Dworniczak B, Boecker W (2001) Monoclonality in normal epithelium and in hyperplastic and neoplastic lesions of the breast. J. Pathol. 193, 27.

Dontu G, Al-Haaj M, Abdullah WM, Clarke MF, Wicha MS (2003) Stem cells in normal breast development and breast cancer. Cell Prolifer 36 (Suppl. 1).

FERGUSON DJ (1985) Ultrastructural characterisation of the proliferative (stem?) cells within the parenchyma of the normal 'resting' breast. Virchows Arch. A Pathol. Anat. Histopathol. 407, 379.

Fuchs E, Segre JA (2000) Stem cells: a new lease on life. Cell 100, 143.

Good P, Yoda A, Sakakibara S, Yamamoto A, Imai T, Sawa H, Ikeuchi T, Tsuji S, Satoh H, Okano H (1998) 
The human Musashi homolog 1 (MSI1) gene encoding the homologue of Musashi/Nrp-1, a neural RNA-binding protein putatively expressed in CNS stem cells and neural progenitor cells. Genomics 52, 382.

Goodell MA, Rosenzweig M, Kim H, Marks DF, Demaria M, Paradis G, Grupp SA, Sieff CA, Mulligan RC, JoHnson RP (1997) Dye efflux studies suggest that hematopoietic stem cells expressing low or undetectable levels of CD34 antigen exist in multiple species. Nat. Med. 3, 1337.

Gudjonsson T, Villadsen R, Nielsen HL, Ronnov-Jessen L, Bissell MJ, Petersen OW (2002) Isolation, immortalization, and characterization of a human breast epithelial cell line with stem cell properties. Genes Dev. 16, 693.

Hoshino K, Gardner WU (1967) Transplantability and life span of mammary gland during serial transplantation in mice. Nature 213, 193.

Imai T, Tokunaga A, Yoshida T, Hashimoto M, Mikoshiba K, Weinmaster G, Nakafuku M, Okano H (2001) The neural RNA-binding protein Musashil translationally regulates mammalian numb gene expression by interacting with its mRNA. Mol. Cell Biol. 21, 3888.

JACKSON KA, Mi T, GoODELl MA (1999) Hematopoietic potential of stem cells isolated from murine skeletal muscle. Proc. Natl Acad. Sci. USA 96, 14482.

JENSEN UB, LOWELl S, WATt FM (1999) The spatial relationship between stem cells and their progeny in the basal layer of human epidermis: a new view based on whole-mount labelling and lineage analysis. Development 126, 2409.

JONES PH (1997) Epithelial stem cells. Bioessays 19, 683.

Kaneko Y, Sakakibara S, Imai T, Suzuki A, Nakamura Y, Sawamoto K, Ogawa Y, Toyama Y, Miyata T, OKANO H (2000) Musashil: an evolutionally conserved marker for CNS progenitor cells including neural stem cells. Dev. Neurosci. 22, 139.

Kanemura Y, Mori K, Sakakibara S, Fujikawa H, Hayashi H, Nakano A, Matsumoto T, Tamura K, Imai T, Ohnishi T, Fushiki S, Nakamura Y, Yamasaki M, Okano H, Arita N (2001) Musashil, an evolutionarily conserved neural RNA-binding protein, is a versatile marker of human glioma cells in determining their cellular origin, malignancy, and proliferative activity. Differentiation 68, 141.

Kolodka TM, Garlick JA, TAichman LB (1998) Evidence for keratinocyte stem cells in vitro: long term engraftment and persistence of transgene expression from retrovirus-transduced keratinocytes. Proc. Natl Acad. Sci. USA 95, 4356.

Kopan R (2002) Notch: a membrane-bound transcription factor. J. Cell Sci. 115, 1095.

Kordon EC, SMith GH (1998) An entire functional mammary gland may comprise the progeny from a single cell. Development 125, 1921.

Korsching E, Packeisen J, Agelopoulos K, Eisenacher M, Voss R, Isola J, Van Diest PJ, Brandt B, Boecker W, Buerger H (2002) Cytogenetic alterations and cytokeratin expression patterns in breast cancer: integrating a new model of breast differentiation into cytogenetic pathways of breast carcinogenesis. Lab. Invest. 82, 1525.

Lakhani SR, Chaggar R, Davies S, Jones C, Collins N, Odel C, Stratton Mr, O’Hare MJ (1999) Genetic alterations in 'normal' luminal and myoepithelial cells of the breast. J. Pathol. 189, 496.

Lakhani SR, Slack DN, Hamoudi RA, Collins N, Stratton MR, Sloane JP (1996) Detection of allelic imbalance indicates that a proportion of mammary hyperplasia of usual type are clonal, neoplastic proliferations. Lab. Invest. 74, 129.

Li P, Barraclough R, Fernig DG, Smith JA, Rudland PS (1998) Stem cells in breast epithelia. Int. J. Exp. Pathol. 79, 193.

Lowell S, Jones P, Le Roux I, Dunne J, Watt FM (2000) Stimulation of human epidermal differentiation by delta-notch signalling at the boundaries of stem-cell clusters. Curr. Biol. 10, 491.

MacKenzIE IC (1997) Retroviral transduction of murine epidermal stem cells demonstrates clonal units of epidermal structure. J. Invest. Dermatol. 109, 377.

McGregor H, Land CE, Choi K, Tokuoka S, Liu PI, Wakabayashi T, Beebe GW (1977) Breast cancer incidence among atomic bomb survivors, Hiroshima and Nagasaki, 1950-69. J. Natl. Cancer Inst. 59, 799.

McKinney-Freeman SL, Jackson KA, Camargo FD, Ferrari G, Mavilio F, Goodell MA (2002) Muscle-derived hematopoietic stem cells are hematopoietic in origin. Proc. Natl Acad. Sci. USA 99, 1341

Michel M, Torok N, Godbout MJ, Lussier M, Gaudreau P, Royal A, Germain L (1996) Keratin 19 as a biochemical marker of skin stem cells in vivo and in vitro: keratin 19 expressing cells are differentially localized in function of anatomic sites, and their number varies with donor age and culture stage. J. Cell Sci. 109, 1017.

Nakamura M, Okano H, Blendy JA, Montell C (1994) Musashi, a neural RNA-binding protein required for Drosophila adult external sensory organ development. Neuron 13, 67.

Okabe M, Imai T, Kurusu M, Hiromi Y, Okano H (2001) Translational repression determines a neuronal potential in Drosophila asymmetric cell division. Nature 411, 94.

OKano H, Imai T, OKaвe M (2002) Musashi: a translational regulator of cell fate. J. Cell Sci. 115, 1355. 
Orkin SH (2000) Diversification of haematopoietic stem cells to specific lineages. Nat. Rev. Genet. 1, 57.

ORMEROD EJ, RudLAND PS (1986) Regeneration of mammary glands in vivo from isolated mammary ducts. J. Embryol. Exp. Morph. 96, 229.

Pechoux C, Gudjonsson T, Ronnov-Jessen L, Bissell MJ, Petersen OW (1999) Human mammary luminal epithelial cells contain progenitors to myoepithelial cells. Dev. Biol. 206, 88.

Perou CM, Jeffrey SS, Van De Rijn M, Rees CA, Eisen MB, Ross DT, Pergamenschikov A, Williams CF, Zhu SX, Lee JC, Lashkari D, Shalon D, Brown PO, Botstein D (1999) Distinctive gene expression patterns in human mammary epithelial cells and breast cancers. Proc. Natl Acad. Sci. USA 96, 9212.

Perou CM, Sorlie T, Eisen MB, Van De Rijn M, Jeffrey SS, Rees CA, Pollack JR, Ross Dt, Johnsen H, Akslen la, Fluge O, Pergamenschikov A, Williams C, Zhu SX, Lonning Pe, Borresen-Dale Al, Brown PO, Botstein D (2000) Molecular portraits of human breast tumours. Nature 406, 747.

Petersen OW, Hoyer PE, Van Deurs B (1987) Frequency and distribution of estrogen receptor-positive cells in normal, nonlactating human breast tissue. Cancer Res. 47, 5748.

Potten CS, Booth C, Tudor GL, Booth D, Brady G, Hurley P, Ashton G, Clarke R, Sakakibara S, OKano H (2003) Identification of a putative intestinal stem cell and early lineage marker; Musashi-1. Differentiation 71, 28.

Potten CS, Loeffler M (1990) Stem cells: attributes, cycles, spirals, pitfalls and uncertainties. Lessons for and from the crypt. Development 110, 1001.

Potten CS, Morris RJ (1988) Epithelial stem cells in vivo. J. Cell Sci. Supplement 10, 45.

PotTen CS, Owen G, Bоотн D (2002) Intestinal stem cells protect their genome by selective segregation of template DNA strands. J. Cell Sci. 115, 2381.

Russo J, Ao X, Grill C, Russo IH (1999) Pattern of distribution of cells positive for estrogen receptor alpha and progesterone receptor in relation to proliferating cells in the mammary gland. Breast Cancer Res. Treat. 53, 217.

Russo IH, Russo J (1978a) Developmental stage of the rat mammary gland as determinant of its susceptibility to 7,12dimethylbenz[a]anthracene. J. Natl. Cancer Inst. 61, 1439.

Russo J, Russo IH (1978b) DNA labeling index and structure of the rat mammary gland as determinants of its susceptibility to carcinogenesis. J. Natl Cancer Inst. 61, 1451.

Saji S, Jensen EV, Nilsson S, Rylander T, Warner M, Gustafsson JA (2000) Estrogen receptors alpha and beta in the rodent mammary gland. Proc. Natl Acad. Sci. USA 97, 337.

Sakakibara S, Imai T, Hamaguchi K, Okabe M, Aruga J, Nakajima K, Yasutomi D, Nagata T, Kurihara Y, Uesugi S, Miyata T, Ogawa M, Mikoshiba K, Okano H (1996) Mouse Musashi-1, a neural RNA-binding protein highly enriched in the mammalian CNS stem cell. Dev. Biol. 176, 230.

Seagroves TN, Lydon JP, Hovey RC, VonderhaAr BK, Rosen JM (2000) C/EBPbeta (CCAAT/enhancer binding protein) controls cell fate determination during mammary gland development. Mol. Endocrinol. 14, 359.

Shoker BS, Jarvis C, Clarke RB, Anderson E, Hewlett J, Davies MP, Sibson DR, Sloane JP (1999) Estrogen receptor-positive proliferating cells in the normal and precancerous breast. Am. J. Pathol. 155, 1811.

Smalley MJ, Titley J, Paterson H, Perusinghe N, Clarke C, O’Hare MJ (1999) Differentiation of separated mouse mammary luminal epithelial and myoepithelial cells cultured on EHS matrix analyzed by indirect immunofluorescence of cytoskeletal antigens. J. Histochem. Cytochem. 47, 1513.

Sмiтн GH (2002) Mammary cancer and epithelial stem cells: a problem or a solution? Breast Cancer Res. 4, 47.

Sмith GH, Chepko G (2001) Mammary epithelial stem cells. Microsc. Res. Techn. 52, 190.

Smith GH, Medina D (1988) A morphologically distinct candidate for an epithelial stem cell in mouse mammary gland. J. Cell Sci. 90, 173.

Smith CA, Monaghan P, Neville AM (1984) Basal clear cells of the normal human breast. Virchows Arch. A Pathol. Anat. Histopathol. 402, 319.

Smith GH, Strickland P, Daniel CW (2002) Putative epithelial stem cell loss corresponds with mammary growth senescence. Cell Tissue Res. 310, 313.

Sorlie T, Perou CM, Tibshirani R, Aas T, Geisler S, Johnsen H, Hastie T, Eisen MB, Van De Rijn M, Jefrrey SS, Thorsen T, Quist H, Matese JC, Brown PO, Botstein D, Eystein Lonning P, Borresen-Dale AL (2001) Gene expression patterns of breast carcinomas distinguish tumor subclasses with clinical implications. Proc. Natl Acad. Sci. USA 98, 10869.

Stingl J, Eaves CJ, KuUsk U, Emerman JT (1998) Phenotypic and functional characterization in vitro of a multipotent epithelial cell present in the normal adult human breast. Differentiation 63, 201.

Stingl J, EAVES CJ, ZANDIEH I, EMERMAn JT (2001) Characterization of bipotent mammary epithelial progenitor cells in normal adult human breast tissue. Breast Cancer Res. Treat. 67, 93.

Taylor-Papadimitriou J, Stampfer M, Bartek J, Lewis A, Boshell M, Lane EB, Leigh IM (1989) Keratin expression in human mammary epithelial cells cultured from normal and malignant tissue: relation to in vivo phenotypes and influence of medium. J. Cell Sci. 94, 403. 
Topley GI, Okuyama R, Gonzales JG, Conti C, Dotto GP (1999) p21 (WAF1/Cip1) functions as a suppressor of malignant skin tumor formation and a determinant of keratinocyte stem-cell potential. Proc. Natl Acad. Sci. USA 96, 9089.

Tsai YC, Lu Y, Nichols PW, Zlotnikov G, Jones PA, Smith HS (1996) Contiguous patches of normal human mammary epithelium derived from a single stem cell: implications for breast carcinogenesis. Cancer Res. 56, 402.

Watt FM (1998) Epidermal stem cells: markers, patterning and the control of stem cell fate. Philos. Trans. R. Soc. Lond. B Biol. Sci. 353, 831.

Wellings SR, Jensen HM, Marcum RG (1975) An atlas of subgross pathology of the human breast with special reference to possible precancerous lesions. J. Natl Cancer Inst 55, 231.

Welm Be, Tepera SB, Venezia T, Graubert TA, Rosen JM, Goodell MA (2002) Sca-1 (pos) cells in the mouse mammary gland represent an enriched progenitor cell population. Dev. Biol. 245, 42.

Young LJ, Medina D, Deome KB, Daniel CW (1971) The influence of host and tissue age on life span and growth rate of serially transplanted mouse mammary gland. Exp. Gerontol. 6, 49.

Zeps N, Bentel JM, Papadimitriou JM, D’Antuono MF, Dawkins HJ (1998) Estrogen receptor-negative epithelial cells in mouse mammary gland development and growth. Differentiation 62, 221.

Zeps N, Dawkins HJ, Papadimitriou JM, Redmond SL, Walters MI (1996) Detection of a population of long-lived cells in mammary epithelium of the mouse. Cell Tissue Res. 286, 525.

Zhou S, Schuetz JD, Bunting KD, Colapietro AM, Sampath J, Morris JJ, Lagutina I, Grosveld GC, Osawa M, NAKAUChi H, SoRrentino BP (2001) The ABC transporter Bcrp1/ABCG2 is expressed in a wide variety of stem cells and is a molecular determinant of the side-population phenotype. Nat. Med. 7, 1028. 